\title{
An Implementable Institutional Reform that Transfers Control of Government Spending Levels from Politicians to Voters
}

\author{
Philip E. Graves* \\ Department of Economics \\ University of Colorado 256 CUB \\ Boulder, CO 80302-0256 \\ e-mail: gravesp@spot.colorado.edu
}

Revised: March 2009

*While absolving the following from blame for remaining errors, I would like to acknowledge the comments of Jim Alm, Jen Barrett, Ann Carlos, Milton Friedman, Peter Mueser, Anna Rubinchik-Pessach, Tom Rutherford, Charles Sawyer, Larry Singell, Larry Sjastad, George Tolley, and Don Waldman. I would also like to acknowledge helpful comments of seminar participants at the University of Chicago, Colorado State University, the University of Wyoming, and the $28^{\text {th }}$ Annual Conference of the Association of Private Enterprise Education. I apologize for any omissions in the preceding list. 


\title{
An Implementable Institutional Reform that Transfers Control of Government Spending Levels from Politicians to Voters
}

\begin{abstract}
Elected representatives have little incentive to pursue the interests of those electing them once they are elected. This well-known principle-agent problem leads, in a variety of theories of government, to non-optimally large levels of government expenditure. An implication is that budgetary rules are seen as necessary to constrain politicians' tax and spending behavior. Popular among such constraints are various Balanced Budget Amendment proposals. These approaches, however, are shown here to have serious limitations, including failure to address the central concern of spending level. An alternative approach is advanced here that relies on a Coase-like mechanism that transfers control of government spending to the voter. Prisoner's dilemma incentives and political competition are seen to be critical to the superiority of the present mechanism to approaches requiring budget balance.
\end{abstract}

Key words: balanced-budget amendments, rent seeking, bureaucracy, scope of government, national budget, deficits, debt, political economy

JEL Classifications: A12, D23, D71, D72, D78, H11, H61, H62, P17 


\section{Introduction}

The failure of our elected representatives to do what the voters wish upon being elected, due in part to special interest power, comprises an important principal-agent problem. As with other principal-agent problems (see Spence and Zeckhauser 1971, Ross 1973), elected representatives do not act in the best interest of those electing them because the former have informational advantages and different interests (see Sappington 1991 for a discussion of principal-agent incentive problems). One might argue that politicians are forced to represent the interests that elected them: to remain in office they want to return to a constituency and tell them that they have either lowered their taxes or brought them program benefits. This would be fine except that a) politicians have, then, an incentive to run large deficits and b) politicians have incentives to promote expenditures that benefit them and not necessarily the American electorate, special interest abuses being of particular interest here.

The preceding problems are well known to public choice theorists (see Buchanan 1962, Olsen 1965 as classic sources among many) and those developing models of government. For example, the special-interest model of government (Stigler 1971, Peltzman 1976, and Becker 1983), the monopoly model (Niskanen 1975), and the Leviathan model (Brennan and Buchanan 1979) all display equilibrium spending that is non-optimally large and budget rules are seen as needed constraints on politicians' tax and spending behavior.

Empirically, averaging over decades to smooth the impact of business cycles, the percent of GDP spent by U.S. governments at all levels, federal, state, and local combined, was 22.8 (1950s), 25.1 (1960s), 28.2 (1970s), and 30.6 (1980s). After small declines in the 1990s (accompanied by the only budget surpluses since 1969 in 1998-2000), the trend of increasing spending shares resumed, culminating in a 36.1 share in $2006 .{ }^{1} \quad$ It would be difficult to argue convincingly that this growth pattern-with the combined government spending share rising from 7 percent in 1902 to a projected 35 percent in 2010-has represented the desires of the American people. However, this possibility not ruled out in the mechanism proposed here to help solve the principal-agent problem in government spending.

The concern here is with the nature of the budgetary rule employed to encourage the government to provide the proper level of expenditure. Past efforts to address the concerns of political scientists, economists, and others have resulted in the various Balanced Budget Amendment (hereafter BBA) proposals. The basic idea of these proposals is to require that the federal budget be annually balanced, except

\footnotetext{
${ }^{1}$ Text numbers are available at: http://www.usgovernmentspending.com/
} 
in times of war or national emergency. In such extreme contingencies, deficits may be run if both the House and Senate vote to do so with a super-majority. A weak form of BBA would allow taxes to be increased to balance the budget if both chambers voted to do so with a simple majority and deficits could be run with a three-fifths majority. The strong form of BBA would require a two-thirds majority to either raise taxes or run a deficit. The presumption, particularly in the strong form of BBA, is that this amendment would work to reduce the size of government.

The present paper provides an alternative approach to resolving the problems briefly sketched above. Section II provides a brief discussion of the numerous limitations of the BBA approaches. A Coase-like mechanism is then briefly proposed in Section III, prior to a discussion of its benefits and when it would not be applicable in Section IV. Further implications are taken up in Section V, prior to a closing summary in Section VI.

\section{The Balanced Budget Amendment Approach}

The BBA proposals have passionate defenders and critics. Many economists are concerned that the BBA proposals would be pro-cyclical in a world characterized as being even slightly Keynesian in nature. Should a mild recession occur, the requirement to balance the budget would cause either exogenous spending cuts or tax increases to offset endogenous expenditure increases (e.g. food stamps, unemployment insurance) and tax revenue reductions at the lower income level, hence the BBA imposes pro-cyclical policy. Recent world-wide stimulus packages designed to prevent a slide from recession to depression would have been thwarted by a BBA in the absence of (the likely) overrides discussed above.

An additional objection stems from variation in preferences regarding the size of government: any BBA would have the practical result of cutting the growth of spending, since tax increases are unpopular. Some people may actually want bigger governments or believe that large overall levels of government spending are a necessary side-effect to reflect the diversity of opinion about which things should be funded. Hence, while one suspects that a majority of the voting population supports smaller government, some may believe that a large government doing many things reduces the tyranny of the majority over the minority.

A third objection to BBA approaches stems from a "ratcheting" phenomenon associated with the business cycle. Economic boomtimes give politicians the ability to dramatically increase spending, since burgeoning tax receipts allow that and spending is popular among the various special interests benefitting from it. However, when the economy cools, required budget balance would (and does at the state level) 
result in either what seem like draconian short-run spending cuts, or large increases in tax rates. The former exacerbate the economic downturn, while the latter set the stage for further revenue growth during the next upturn. Indeed, as recently as the year 2001, the U.S. baby-boomer demographic phenomenon and improved productivity growth seemed to suggest that surpluses would continue for decades, making the BBA issue seem politically irrelevant. Given the incentives facing politicians, however, it is hardly surprising that large expenditure increases combined with tax cuts have reemerged. Had the terrorist acts in the early 2000s and the recession of 2007 not occurred to justify large spending increases and tax cuts, past trends suggest that more typical pork barrel/earmark projects would have emerged to swallow any predicted surpluses.

I propose here an alternative approach to achieving the benefits of a BBA, along with many other benefits, without the BBA drawbacks emphasized by its detractors. It will be seen that the mechanism advanced here directly addresses the principal-agent problem of politicians poorly representing constituent interests, as opposed to BBA proposals that skirt the central problem.

To motivate this alternative approach, it is useful to examine more closely the basic flaw in the current governmental system that has led to the advocacy of a BBA. ${ }^{2}$ The flaw, well-known to public choice specialists, is that politicians, once elected, make decisions to spend that do not accurately reflect the social benefits and costs of that expenditure. In particular, regardless of the spending platforms the candidates of Parties vying for the presidency run on, once they are, in fact, elected decisionmakers they have incentives to take actions with benefits greater than costs to them and their Party. Hence, projects that provide concentrated benefits for special interest groups but greater costs to the general tax-paying populace are enacted into law, despite the fact that such projects lower the value of our nation's scarce resources.

However, by narrowly focusing on deficits, the BBA only indirectly controls the share of our resources being devoted to government goods. Clearly it is the level of spending that is of importance, with financing being a secondary concern. Under Ricardian Equivalence, if taxes are raised to prevent a deficit, the assets cashed to pay the taxes fail to earn the interest that would have enabled payment of the future tax

2

This flaw exists globally at all levels of government, although the text discussion emphasizes the U.S. federal government level to parallel the BBA approach. The recommended palliative might be most easily implemented in a parliamentary system or at a state level. As the mechanism began to receive broad voter acceptance, it would spread to non-parliamentary systems having existing institutions hindering its initial implementation. 
burden. Alternatively, if a deficit is run, the assets retained by the taxpayers earn interest allowing payment of the higher future tax burden. That it has been difficult to find impacts on interest rates from deficits of historically typical size suggests that Ricardian Equivalence has relevance in the present context, even if some consumers do reduce consumption to pay taxes.

\title{
III. A Simple Mechanism to Transfer Control of Spending to the Voter
}

The incentive-correcting institutional reform mechanism proposed here hinges on 1) effective political contracts and 2) pronounced political competition. It may be characterized as a variation on the Coase Theorem (see Coase 1960) combined with a political game involving reputation. A central insight of the mechanism is that the assignment of property rights in the damages from political behavior has an important impact on the size of the transactions costs associated with that behavior. But, political competition among the Parties vying for election will be seen to be critical to the proper working of the mechanism to give the voters what they desire, eliminating the principle-agent problem. The mechanism, hereafter M, is as follows:

\begin{abstract}
"Any Party wishing to be place a candidate on the ballot for an impending election, must (in addition to existing requirements) indicate the total spending, $S$, that it will incur over the fouryear term of election. ${ }^{3}$ If the elected officials of the Party spend more than $S$, the Party is itself liable to pay any amount exceeding $S$ into a fund that will be used to retire the national debt, except under specific circumstances to be discussed further below."
\end{abstract}

\footnotetext{
${ }^{3}$ That is all they need indicate. In particular, politicians in the elected Party can spend that budget in any way they want and they can even talk in the speeches prior to the election about spending it one way and, in fact, spend it in another way. Moreover, they can have complete flexibility as to how they allocate their promised total spending among the four years. After all, the future cannot be predicted, and the implications of that uncertainty will be developed more fully in the main text. Moreover, if they did not keep under their own stated $\mathrm{S}$ they will be seen to be irrational, and are very likely in any event either to go bankrupt or to be replaced at the next election. Since parties aren't irrational, it is unlikely that there will ever in fact be any money in the "fund." That was incorporated into $\mathrm{M}$ to aid the reader in understanding, as the Coase point is subtle and the notion of a fund makes it easier to comprehend in this setting. The political Party that wins the election will likely wish, as at present, to indicate the amount $S_{i}$ that they will spend in each of the ith years, $i=1-4-$ but only as the years roll around. The timing of the announcement of $S$ could be debated.
} 
Imposing the preceding conditions, $\mathrm{M}$, will prevent spending increases subsequent to election that are often associated with special interest group power. This follows from the fact that programs involving expenditure that would exceed $\mathrm{S}$, will have costs, under $\mathrm{M}$, that are born by the decision making Party, rather than by the American people. Hence there will generally be no amount that a special interest group would be willing to pay, that will be accepted by the decision maker. This Coase-like outcome presumes that programs being considered, on the margin, will have costs greater than benefits to society as discussed further below. Should a proposed program violating the $\mathrm{S}$ constraint have benefits to special interests that are greater than costs, the political party could be compensated-and the program, which should on efficiency grounds have occurred anyway might well be adopted.

\section{The Mechanism's Benefits: Discussion And Exceptions}

The mechanism being advocated may best be understood in the context of pollution. Under the Coase Theorem, if transactions costs are sufficiently small, the efficient outcome will occur regardless of the assignment of property rights in pollution. But, property rights must be clearly defined. Increasingly, property rights in pollution are being assigned to households rather than to firms (e.g. the Exxon Valdez penalties). Non-optimal pollution continues to occur in cases where that pollution has small damages relative to transactions costs, e.g. when millions of widely-dispersed damage receptors receive damages that are individually small relative to the costs of "getting involved."

Historically, the politicians representing political Parties have had property rights in political promises, and the net damages to individual voters from any specific program have, likewise, been small relative to the transactions costs of involvement. Illustrating, under the current system, the overall budget might grow due to funding a project having concentrated benefits of $\$ 60$ million and costs of $\$ 100$ million. This project could get funded because a portion of the benefits could be allocated to the politicians (e.g. $\$ 10$ million in PAC contributions or other less savory payoffs), while the American people will be paying for the project. With more than 100 million households, the cost to each household would be less than a dollar, hence it would not be in the interest of voters to even know about such projects, much less to use scarce resources to resist such programs. Thus, upon being elected and becoming the decision-makers, politicians (netting $\$ 10$ million) in concert with special interests (netting \$50 million) would pass legislation funding this project and perhaps many other projects having costs greater than benefits collectively. Note that many inefficient policies are enacted (e.g. milk price supports) 
with near-unanimous support, since both Parties are receiving special interest support in case the "wrong" Party gets elected.

Under M, however, the political representatives of the controlling Party would be unwilling to fund the project, since the most they could possibly be offered by the special interests would be $\$ 60$ million for passage, but it would cost them $\$ 100$ million (rather than the American people, as at present) if S increased in order to fund this project. $\mathrm{M}$, then, eliminates the transactions cost problem that has prevented the Coase Theorem from being operative in the political context. Once $S$ is established, inefficient projects will, under $\mathrm{M}$, no longer result in overall budget increases after the elected Party takes office.

One might argue that too many projects, efficient and inefficient, would still be included in overly large S's offered by the Parties vying for office. This is, of course, a problem in the current system and remains so, perhaps to a somewhat lesser degree, under a BBA-a large, but balanced budget could contain many inefficient projects. Under $\mathrm{M}$, however, political competition will tend to give Americans the overall level of government expenditure they wish over time, regardless of budget balance. Note that this eliminates one of the criticisms of BBAs: it is commonly felt that a BBA is just a ruse to halt spending growth, while some people really want more, not less, spending. Under M, if Americans want bigger government they can vote for the Party offering a larger S. But, one must strongly suspect that the median voter (plus many) would, in fact, like to have smaller more efficient government (on the median voter model, see Downs 1957). Competition among political parties will turn to the efficiency and equity implications of proposed spending within the overall limit, with reasonable prospects that inefficient projects will get noticed.

As noted in introductory comments, there have been substantial increases in the percentage of income being spent by government. The observed growth in total spending has occurred regardless of which Party is in power, which is as expected given the faulty incentive mechanism presently operative. It would seem likely, under $\mathrm{M}$, that the Party whose candidates ultimately win the national election would propose at least modest expenditure cuts, say an initial rollback to 19.5 percent of GDP (20.3 percent was the actual figure for 2006), with political competition likely to force percentages lower in future elections.

Since overall governmental spending will be limited by the $\mathrm{S}$ of the elected Party, focus will shift to the efficiency and equity implications of the composition of that spending. We would, increasingly over time, expect Parties wishing their candidates to be elected to offer public goods in the relative amounts that the median voter desires. This does not, of itself, necessarily imply that programs would become more efficient. People, in virtually any country rich enough, appear to have an 
affinity for agricultural policies, for example, that are resource wasting. Moreover, it is difficult to measure benefits and costs for many government programs, so increases in efficiency (within an overall S) might be expected to be slow in emerging. ${ }^{4}$

It might be argued that the elected political Party can only "try" to deliver its promises, but there may be cases in which it is unable to do so. ${ }^{5}$ If this is so, it might be widely viewed as unfair to require that the elected Party be liable for spending in excess of S. Three important cases of this problem come to mind. First, a national disaster (e.g. the terrorist attacks, a deep recession, or a major earthquake) in some future year might occur after a party, promising to spend S, has been elected. In such cases, a Congressional vote could be taken as to whether a temporary $\Delta \mathrm{S}$ would be warranted, that would not count against the Party's S, using the same super-majority rules as advocated under a BBA. This extraordinary event will not go unnoticed by the American people, hence will be reserved for true emergencies, and will not be commonly available as a means of getting around the impact of $\mathrm{M}$.

Note that for minor disasters, wars, and the like, funds can be moved among different expenditure classifications within the overall S. For example, money could be moved from social programs to defense should a small unanticipated war break out. Or, conversely, a minor disaster might involve transfers from the military accounts to FEMA or other aid agencies.

Second, what of spending that is beyond the control of politicians, being built into the system and dependent on the level of income? The "built-in stabilizers" of the Keynesian model come to mind. Indeed, this is one of the most pervasive criticisms of the BBA. In that context, the potential pro-cyclical implications might indeed be a problem, since the focus of the BBA is on deficits, rather than the truly important concern, the level of S. These endogenous spending variations (e.g.

4

Many inefficient programs are, however, quite easy to analyze (e.g. the agricultural policies). Efficiency gains from agricultural program reforms or eliminations could be combined with transfers to make all farmers better off, if that were deemed fair. If the political concern were with poor farmers being forced from family farms, a means-based test could be applied and more of the efficiency gains could be returned to the American people in the form of lower prices for food.

5

Indeed, a New York Times/CBS News Poll indicated that only "two in 10 voters said they thought it was possible for presidents to fulfill their promises." The article reporting the poll results, went further indicated that "voters were overwhelmingly pessimistic about the likelihood that either candidate would accomplish much as president...(being) inevitably hamstrung by the whims and desires of Congress and special interest groups." (Berke and Elder, Nov. 6, 2000). 
unemployment insurance, food stamps) may indeed be desirable, and these too need not count toward S, under this (debatable) variant of M.. The critical thing is that exogenous increases in spending that ultimately violate $\mathrm{S}$ not be allowed; this is guaranteed by $\mathrm{M}^{6}$

Finally, what if a candidate of Party A, promising to spend $\mathrm{S}$, is elected to the presidency, while another Party B controls one or both of the House of Representatives or Senate? This is a particularly important difficulty with the implementation of $\mathrm{M}$ in political systems like those in America. The mechanism advocated here might most easily be first adopted in a country having a parliamentary system, since the majority party (or coalition ${ }^{7}$ ) appoints the prime minister, eliminating this problem. Should the executive and legislative branches be split, the Party of the president would not be liable for spending mandated by Congress upon it. ${ }^{8}$ However, it should be pointed out that it would generally be irrational to elect a Congress controlled by a Party that differed from the President's Party; the voters would be thwarting their own desires to obtain the $\mathrm{S}$ that they themselves prefer.' There are those who might be unable to understand the discussion herein, but most people will be able to see that voting a split-ticket would create unnecessary problems. Over time, a majority would certainly be expected to vote for the Party of the president for control of Congress in any event. ${ }^{10}$

6

It is also possible, though perhaps non-preferable, that recessions could be handled as with major disasters, leaving the Party in power responsible for minor fluctuations, turning to Congress only in major downturns.

7

Any excess of spending over S could be allocated to coalition Parties in proportion to their representation in the coalition.

8

Whether there should be a requirement of a presidential veto, hence a two-thirds vote to over-ride that veto, is likely to ultimately be moot as will be seen.

9

It might be rational for voters in particular jurisdictions to vote to retain those in office with sufficient "clout" to have delivered (in the past) projects with net benefits to those jurisdictions, despite the projects having social costs exceeding benefits. But, for the critical median voter, the marginal project (that would increase spending beyond S) is likely to be undesired.

10

Recent trends toward splitting control of the Executive and Legislative branches, are likely due to voters desires to have less "accomplished," a motivation eliminated by M. This was clearly 
The $\mathrm{S}$ number is not difficult to calculate. It is the actual dollar amount of spending over the time until the next election (auditors ${ }^{11}$ can calculate the expenditures, where "future promises" to spend are, on the whole, valueless if they are to occur in an election period further out than the present four-year period). Indeed, the information requirements under $M$ are less onerous than those of the various BBAs, since the latter require annual numbers for both expenditures and revenues. For large projects that can only be completed in a longer time-frame, only expenditures in the current period count against the current period, while expenditures in future periods will be included in the $\mathrm{S}$ of the current Party running for re-election. If that Party does not get re-elected, it is possible that some such projects would be eliminated, for sunk costs are, after all, sunk. Indeed, voters might wish to vote against the incumbent Party precisely to halt certain projects (e.g. "Star Wars" defense initiatives, perhaps). Should, however, the newly-elected Party wish to continue long-time-frame projects from a prior administration (as might be expected if such projects have marginal benefits in excess of marginal costs or if they were popular regardless of efficiency considerations), they must take responsibility for this in their $\mathrm{S}^{\prime}$.

The political Parties running candidates for office might, especially initially, be expected to be risk averse, running on a higher $S$ than they really plan on spending, to offset fears of accidental excess spending that they would be liable for under M. There is no a priori reason to expect that the resulting surpluses would be undesirable, and, with experience, this reason for their existence should diminish, in any event.

Why would political Parties submit to M? As the implications discussed here become well-known, the populace would demand that a law or constitutional amendment enforcing $M$ be passed-such a law is superior to the BBA that would likely already have been passed had surpluses not (temporarily) emerged during the

\footnotetext{
expressed in William Safire's November 7, 2000 New York Times column entitled "Be Sure to Split that Ticket, Because Gridlock is Good." Fewer pork-barrel projects are approved if the branches are split, but the $\mathrm{S}$ limitation under $\mathrm{M}$ accomplishes the same goal without splitting tickets-the Party in power will be able to spend what they said they would and will wish to spend no more under M. Many existing "checks and balances" become both unnecessary and actually obstructive when $\mathrm{M}$ is operative.

11

The auditing function is quite important and might be conducted by the nonpartisan General Accounting Office. One could also argue for setting up an independent agency, analogous to the Federal Reserve, for this purpose. Or, a major accounting firm could be employed as is the case with large corporations, in the context of smaller state and local governmental units.
} 
late-1990s. The candidate of any Party unwilling to support such a law would be revealed as wanting to continue the pork-barrel status quo that has been enlarging the scope of government in America, and most other countries, for at least the last century.

Passage of a law enforcing M might not actually be necessary, if verifiable, nonpartisan auditing procedures are agreed upon. If proper auditing is assured, it is possible that competition among the Parties (and pressure from the media) would result, in a few short years, in at least one major Party agreeing to abide by $\mathrm{M}$, subject to the three exceptions discussed above. The Party first agreeing to abide by $\mathrm{M}$ will enhance its probability of winning the election. ${ }^{12}$ For example, suppose that the Republicans agreed to abide by $\mathrm{M}$ and ran on a platform of $\mathrm{S}$, where $\mathrm{S}$ is five percent smaller than the budget of the prior administration. It seems likely that the Democrats, in order to compete in that election (or the next!), would be forced to also agree to abide by $\mathrm{M}$, perhaps offering a similar $\mathrm{S}$, though with a different pattern of sub-category spending, perhaps one with more appeal on equity grounds.

\section{Further Implications of the Mechanism}

There is great political competition in the present form of government in the United States and in many other countries. This is good, and is critical to receiving the longrun benefits of adopting the mechanism proposed here. Because of that competition, candidates of Parties hoping to get, and remain, elected will have incentives to incorporate, within their fixed S, policies that are seen by voters as equitable and efficient insofar as either can be readily determined. Little in the way of enforcement will be needed (assuming the auditing process is relatively unambiguous), because $\mathrm{M}$ is self-policing. The Parties, the politicians representing them, and the majority voters will have, under $\mathrm{M}$, engaged in a voluntary transaction having benefits greater than costs; mechanism $M$ greatly reduces the principal-agent problem discussed at the outset. Enforcement is analogous to enforcement of any other contract made in society. The assignment of the property rights as indicated under M largely

\section{2}

The situation is likely to parallel the classic Prisoner's Dilemma. Both major Parties would be better off if neither submitted to $M$, but if either submits and the other does not, the one submitting is very likely to win a close election (and perhaps many future ones). Hence, both Parties may submit, despite that making each less well off than if neither did...collusion will be difficult to maintain given the pressures of the media in pressing the Parties to explain why they are unwilling to submit. Politics being a repeated game, reputational impacts further support the desirable consequences of $\mathrm{M}$; in particular, bankruptcies resulting from exceeding $\mathrm{S}$ are unlikely. 
eliminates the need for policing, apart from the auditing function. ${ }^{13}$ In ambiguous cases (which would likely be rare), courts could decide whether the conditions of the "contract" had been violated.

One would increasingly expect transfers to the poor to involve means-tests, with inefficient policies that were previously rationalized as "helping the poor" (but that, of course, helped many special interest groups of means) being replaced by more efficient and equitable approaches that would enable Party candidates to run on smaller S's.

Elected representatives of the Party in control will be more likely to seek programs that are either efficient or appeal to the median voter under $\mathrm{M}$, since that will make their $\mathrm{S}$ more appealing. It is probable that technical abilities in the area of applied benefit-cost analysis will grow and be applied not only to programs contained in $\mathrm{S}$, but also regulatory rulings. With Parties constrained by their S's, debate might be expected to turn, more than at present, to important issues of the regulatory burden.

One might initially suspect that the possibility of a recession could loom large if $\mathrm{M}$ came into being. However, significant dislocations are unlikely, since candidates of Parties wishing to be elected, but fearing over-spending, are likely to offer (at least initially) conservative S's akin to recent past spending. Moreover, any dislocations that do occur will present a far less significant problem than is the case with the BBA, since the potential pro-cyclical nature of the latter is eliminated by M's focus on exogenous spending, not on budget balance.

Everything argued here applies with equal force for state and local governments which spend two-thirds as much as the federal government and where spending as a percent of GDP has doubled from 7 percent in 1953 to about 14 percent today. ${ }^{14}$ Indeed, one means by which imposition of $\mathrm{M}$ might spread is for states to implement it first. Nebraska, in particular, has but one house, reducing the potential

13

There will, under M, be heightened "internal" policing of politicians in the Party that is in control. Every congressional member has an incentive to deliver the goods to their constituents. The overall expenditure level is analogous to the "commons," with each member trying to get as much of the (expandable, under the current system) total expenditure delivered to their district as possible. With the overall expenditure constrained under $\mathrm{M}$, politicians might get jurisdictional spending in proportion to an historical average, or expenditure might be allocated more nearly in line with taxes paid by districts, or equity concerns might result in more largesse going to poorer districts, etc. The inevitable discussion of such allocation issues is, it would seem, an additional benefit of M.

${ }^{14}$ See http://newfederalism.urban.org/html/anf_27.html 
for splits among house, senate, and executive branch. The benefits discussed here would result in the spread of $\mathrm{M}$ among the states, ultimately to the federal government. Moreover, countries with a parliamentary system should be able to readily adopt the mechanism.

Much is made of the low voter turnouts in American elections. ${ }^{15}$ Part of this might be due to the suspicion on the part of the voters that-once elected-the Party in control (often in concert with the opposition party, since they may also receive special interest benefits) will do whatever it wishes, regardless of promises made to the American people in the debates leading up to election. Under M, the voter turnout is likely to be much higher than in the past, since voters will be assured of getting the $\mathrm{S}$ that they vote for.

The implementation of $\mathrm{M}$ is likely to have several additional benefits vis-avis the status quo: First, it should allow real incomes to grow at supra-normal rates as long as political competition results in the $\mathrm{S}$ of the elected party being a smaller percentage of GDP over time, presuming the rate of return to investment is higher in the private sector. Second, it is likely to encourage privatization of things that should never have been centrally-planned in the first place. Third, there will be more incentive to find low-cost suppliers (e.g. the anecdotal $\$ 600$ coffee pots). Fourth, the tendency for agencies to spend heavily prior to the end of a fiscal year (the "use it or lose it" syndrome) would be discouraged by the Party in charge. This is so since the Party could save these resources for either future contingencies or for advertising that they "did what they said they would and came in under budget." These effects will be enhanced to the extent that political competition also leads to the gradual elimination of inefficient projects infra-marginally in the scramble to offer the voter lower S's.

There will be fewer non-salary inducements to seek elected office as the special interest group grip on politics wanes (at least on the margin). It is likely, then, that salaries of our elected officials will have to be increased to lure competent candidates from other pursuits, this being surely preferred to the "backroom compensations" of the present system.

15

From over 63 percent in 1960, the percentage of Americans voting in presidential elections has steadily declined (with a small up-tick in 1992) to only 51.7 percent in 1996 (see http://www.fec.gov/pages/htmlto5.htm ). However, McDonald (2008) argues that for recent presidential elections (e.g. $61.6 \%$ for the 2008 election), voter behavior has returned to the levels of earlier years. This does not negate the text assertion that implementation of the proposed mechanism would be expected to increase the number of voters. 


\section{Summary}

The United States and many other nations have done quite well despite an important flaw in the incentives facing politicians. The flaw, a type of principal-agent problem, is that politicians promoting programs do not act upon social considerations of efficiency and equity, but rather upon benefits and costs as seen by them. The costs of incremental programs are paid for by the many millions of American taxpayers. Hence, by transferring even a small portion of the benefits received by special interest groups to politicians, it becomes in the interests of politicians to pass inefficient legislation.

An alternative incentive mechanism is proposed here that eliminates the incentive for politicians, often in concert with special interest groups, to increase a pre-specified budget. The institutional reform mechanism is simple. It makes political Parties responsible for any exogenous spending in excess of the amount promised in the election campaign. This Coase-like mechanism transfers liability for the costs of political promises to those making them, eliminating the market failure that resulted from the high transactions costs of taxpayer involvement in the current system. It would seem that the mechanism would be an easy sell to the American public, since all it would really do is prevent politically-motivated lying about intentions to spend, and lying is widely unpopular.

Many of the longer-run benefits stemming from the mechanism are a result of political competition. That competition has been very intense. While the political competition would remain high under $\mathrm{M}$, it would move toward better pleasing the voter rather than pleasing politicians and special interest groups.

It should be noted, however, that even special interest groups, collectively, might be better off under M. Much lobbying expense is "defensive" in nature, being undertaken to offset lobbying efforts of broadly-defined competitors in the political arena. Additionally, much lobbying is undertaken for projects that have benefits greater than costs; such projects might well have been undertaken in any event, rendering special interest expenditures unnecessary. Lobbying expenses to be the "chosen" contractor for a project should be at least somewhat reduced under M because the political pressure to keep $\mathrm{S}$ low will tend to result in the lowest bid contractor being selected under $M$. Hence, under $M$ one would expect more resources to be put into activities in which firms have expertise and fewer into political manipulation, raising the welfare of the American people.

The mechanism proposed here is superior to the various Balanced Budget Amendments in achieving the desires of the American people. It is the size of expenditure that is of primary importance, not whether there is a budget deficit or 
surplus. Moreover, the potentially pro-cyclical nature of the BBA is not a problem with the present mechanism, particularly if a variant is chosen that does not count endogenous expenditure increases toward S. Finally, while one suspects that typical Americans of either Party would prefer smaller government, the present approach does not unequivocally move in that direction, unlike (particularly) the strong form of BBA. Hence, if Americans would prefer greater government expenditure, perhaps because of the package of programs comprising it, they are free to vote for a Party offering a larger $\mathrm{S}$.

Indeed, the only groups harmed by the proposed mechanism $M$ are the political Parties themselves. Having property rights in the ability to lie about expenditure levels makes the Party winning the election much better off. ${ }^{16}$ Finally, while it might be determined that the proposed mechanism, M, would require a constitutional amendment, it is not obvious that this is necessary. Political competition might result in strong Prisoner's Dilemma-type pressures to adopt $\mathrm{M}$-the Party first agreeing to abide by $\mathrm{M}$ would likely be regarded very favorably, possibly staying in power until competing Parties also agreed to adopt $\mathrm{M}$. The pressure of the American media, properly focused, should not be under-emphasized. If "we, the people" clamor for it, the Parties will eventually voluntarily adopt, or be forced by legislation to adopt, the institutional reform mechanism advocated here.

\section{References}

Becker, G. (1983) “Competition Among Pressure Groups for Political Influence,” Quarterly Journal of Economics 98 (3): 371-400.

Berke, R.L. and J. Elder. (November 6, 2000) "Campaigns don't get much closer than this one," The New York Times.

Brennan, G., and Buchanan, J. (1979) "The Logic of Tax Limits: Alternative Constitutional Constraints on the Power to Tax," National Tax Journal 32 (2): 11-22.

Buchanan, J. (1962) The Calculus of Consent. Ann Arbor: University of Michigan Press.

16

If this damage to the political Parties is viewed as unfair, a fixed amount of funding could be provided by government (perhaps set at actual expenditure in some hopefully-not-too recent election) to all Parties receiving more than some minimal percent of the popular vote. Having done this, there would be no reason to allow any corporate or individual campaign or other contributions, and they could be made illegal, if this were desired. 
Coase, R. (1960) "The problem of social costs," Journal of Law and Economics, 3, pp. 1-45.

Downs, A. (1957) An Economic Theory of Democracy. New York: Harper \& Row. McDonald, Michael P. (2008) "The Return of the Voter: Voter Turnout in the 2008 Presidential Election," The Forum: Vol. 6 : Iss. 4, Article 4.Available at: http://www.bepress.com/forum/vol6/iss4/art4

Niskanen, W. (1975) "Bureaucrats and Politicians," Journal of Law and Economics 18 (3): 617-43.

Olson, M. (1965) Logic of Collective Action. Boston: Harvard University Press.

Peltzman, S. (1976) "Toward a More General Theory of Regulation," Journal of Law and Economics 19 (2): 211-40.

Ross, Steven, (1973) "The economic theory of agency: The principal's problem," American Economic Review, 63(2): 134-139.

Safire, W. (November 7, 2000) "Be Sure to Split that Ticket, Because Gridlock is Good," The New York Times.

Sappington, D. (1991) "Incentives in principal agent relationships," Journal of Economic Perspectives 3(2): 45-66.

Spence, M. and R. Zeckhauser (1971) "Insurance, information and individual action," American Economic Review 61(2): 380-387.

Stigler, G. (1971) "The Theory of Regulation," Bell Journal of Economics 2 (1): 321. 